\title{
Pengaruh Earnings Management, Profitabilitas dan Size terhadap Agresivitas Pajak
}

\author{
Candra Febrilyantri \\ Program Studi Akuntansi, Universitas PGRI Madiun, Indonesia \\ Email: candrafebrilyantri@gmail.com
}

\begin{abstract}
This research aims to test the influence of profit management, profitability and the size of companies on tax aggressiveness. The research population is a manufacturing company registered in IDX of the automotive sub-sector in 2015-2019. The method in sampling this study uses purposive random sampling with a total of 55 samples companies. The method of analysis used is multiple regression analysis techniques. The results showed that earnings management had no effect on tax aggressiveness, profitability had an effect on tax aggressiveness, and corporate size had an effect on tax aggressiveness. The implications of this research are expected by entrepreneurs and the public to be aware of the obligation of taxation to pay taxes in order to make Indonesia's economy better and more stable.
\end{abstract}

Keywords: Tax Aggressiveness, Profitaility, Size, Earnings Management

\begin{abstract}
Abstrak
Penelitian ini bertujuan untuk menguji pengaruh manajemen laba, profitabilitas dan ukuran perusahaan terhadap agresivitas pajak. Populasi penelitian adalah perusahaan manufaktur yang terdaftar di BEI sub sektor otomotif tahun 2015-2019. Metode dalam pengambilan sampel penelitian ini menggunakan purposive random sampling dengan jumlah sampel sebanyak 55 perusahaan. Metode analisis yang digunakan adalah teknik analisis regresi berganda. Hasil penelitian menunjukkan bahwa earnings management tidak berpengaruh terhadap agresivitas pajak, profitabilitas berpengaruh terhadap agresivitas pajak, dan size perusahaan berpengaruh terhadap agresivitas pajak. Implikasi dari penelitian ini diharapkan para pengusaha ataupun masyarakat menyadari mengenai kewajiban perpajakan untuk membayar pajak agar perekononomian Indonesia yang lebih baik dan stabil.
\end{abstract}

Kata Kunci: Agresivitas Pajak, Profitailitas, Size, Earnings Management

\section{PENDAHULUAN}

Pajak adalah penerimaan negara untuk membantu menjalankan roda pemerintahan karena merupakan unsur penerimaan negara paling besar. Di Indonesia, sistem yang dianut adalah Self Assesment, yaitu wajib pajak diberi kepercayaan dan tanggung jawab untuk menghitung, menyetor dan melaporkan kewajiban pajaknya. Sesuai dengan undang-undang perpajakan yang berlaku, setiap perusahaan yang didirikan dan berkegiatan di Indonesia merupakan wajib pajak yang dituntut melakukan kewajiban perpajakan dan menjalanakan self assessment. Namun dalam pelaksanaanya, masih terdapat hambatan dalam sistem ini. Bagi perusahaan atau pemilik perusahaan, pajak dianggap sebagai beban yang akan mengurangi laba perusahaan. Karena tujuan utama didirikannya perusahaan adalah untuk memaksimalkan laba bagi kesejahteraan pemegang saham, maka dengan kondisi ini menyebabkan banyak perusahaan mencari cara penghindaran atau penghematan pajak agar dapat meminimalkan pajak terutang untuk mencapai laba yang optimal. Hal ini telah dikemukakan (Chen, 2010) yang menyatakan bahwa perusahaan cenderung menjadi agresif dalam perpajakan dan melakukan agresivitas pajak untuk meminimalkan biaya pajak agar meningkatkan laba perusahaan.

Menurut (Suandy, 2008) terdapat lima motivasi manajemen dalam melakukan agresivitas pajak, yaitu: 1) kebijakan perpajakan Indonesia yang menganut self assessment dimana wajib pajak bisa menghitung sendiri besar pajaknya, membuka peluang bagi manajer untuk mengimplementasikan praktek agresivitas pajak, 2) Undang-undang perpajakan masih terdapat 
celah bagi wajib pajak untuk menganalisis secara cermat kesempatan untuk merencanakan pajaknya, 3) Administrasi perpajakan, dimana hal ini mendorong perusahaan melaksanakan perencanaan pajak dengan baik agar terhindar dari sanksi administrasi maupun pidana karena adanya penafsiran antara aparat fiskus dan wajib pajak akibat luasnya peraturan perpajakan, 4) Loopholes, tujuan perusahaan untuk memaksimalkan nilai perusahaan dengan cara memperoleh laba maksimum, dan mengurangi biaya-biaya salah satunya dengan meminimalkan pajak anpa melanggar undang-undang pajak, 5) Tarif pajak, dengan adanya perbedaan tarif pajak atas objek pajak, memotivasi perusahaan untuk memanfaatkan agar beban pajaknya rendah.

Agresivitas pajak adalah kegiatan perencanaan pajak (tax planning) semua perusahaan yang terlibat usaha mengurangi tingkat pajak yang efektif (Nugraha, et al., 2015). Terdapat beberapa faktor yang diprediksi mempengaruhi tingkat agresivitas pajak, salah satunya adalah manajemen laba (Earnings Management). Manajemen laba dapat di definisikan sebagai intervensi manajemen dengan sengaja dalam proses penentuan laba untuk memenuhi tujuan pribadi (Schipper, 1989). Manajemen laba merupakan usaha manajer untuk memanipulasi laporan keuangan dengan sengaja dalam batasan yang dibolehkan dalam prinsip-prinsip akuntansi. Semakin agresif perusahaan melakukan manajemen laba, maka semakin tinggi pula tingkat agresivitas pajak perusahaan sehingga beban pajak semakin kecil. Kasus yang baru terjadi yakni dugaan yang melibatkan PT Adaro Energy mengenai pengurangan pembayaran pajak dibantu oleh anak perusahaan di Singapura dan menibulkan potensi pembayaran pajak lebih rendah dari seharusnya sebesar US \$125 juta. Prinsip manajemen laba adalah metode yang dipilih dalam menyajikan informasi laba kepada publik yang sudah disesuaikan dengan kepentingan pihak manajer atau pihak perusahaan. Menurut (Scoot, 2009) salah satu motivasi manager dalam melakukan manajemen laba adalah motivasi pajak, yaitu praktik manajemen laba dilakukan untuk menurunkan pajak penghasilan. Penelitian mengenai hal manajemen laba ini telah dilakukan oleh (Suyanto, et al., 2012) dengan hasil yaitu manajemen laba berpengaruh signifikan dan positif terhadap agresivitas pajak perusahaan. Namun penelitian yang dilakukan (Cahyani, 2012) mengungkapkan bahwa manajemen laba tidak berpengaruh terhadap agresivitas pajak.

Selain Earnings Management, agresivitas pajak juga dipengaruhi oleh ukuran perusahaan (size) (Tiaras, et al., 2015). Ukuran perusahaan merupakan suatu identitas perusahaan berdasarkan skala untuk melihat besar kecilnya ukuran suatu perusahaan. Ukuran perusahaan dapat menunjukkan kemampuan perusahaan pada tindakan pengembalian dan keputusan perpajakannya. Semakin besar ukuran perusahaan, maka akan semakin diawasi pemerintah dan hal ini menimbulkan dua kemungkinan yaitu kecenderungan berlaku patuh (compliance) atau menghindari pajak (Kurniasih, et al., 2013). (Siefgried, 1972)menyatakan bahwa dalam teori kekuasaan politik, semakin besar ukuran sebuah perusahaan, maka akan semakin besar sumber daya yang berkualitas sehingga perusahaan tersebut dapat menggerakkan untuk memanipulasi dan terlibat dalam perencanaan pajak serta mengatur aktivitas-aktivitas yang dapat meminimalisir beban pajakBerdasarkan hasil penelitian yang dilakukan oleh (Tiaras, et al., 2015), Size perusahaan mempengarui perilaku agresivitas pajak dan bersifat positif, sehingga dapat diartikan bahwa perusahaan skala besar cenderung akan melakukan tindakan agresivitas pajak. Namun penelitian yang dilakukan oleh (Nugraha, 2015) menunjukkan hasil bahwa ukuran perusahaan tidak berpengaruh terhadap agresivitas pajak.

Profitabilitas adalah salah satu acuan pengukuran kinerja perusahaan dan dapat mempengaruhi adanya agresivitas pajak. Profitabilitas akan menggambarkan hubungan antara penjualan dan beban, sehingga dapat dilihat kemampuan dalam menghasilkan laba. Tingkat profitabilitas yang tinggi mencerminkan kemampuan entitas dalam menghasilkan laba yang lebih 
tinggi. Perusahaan yang memiliki keuntungan harus mempersiapkan pajak yang dibayarkan sebesar pendapatan yang diperoleh. Perusahaan dengan profitabilitas yang tinggi akan membayar pajak dengan nominal tinggi, begitu pula sebaliknya (Lestari, et al., 2016). Namun penelitian yang dilakukan oleh (Ardianyah, et al., 2014) menyimpulkan bahwa profitabilitas mempunyai arah yang negatif, artinya perusahaan yang memiliki tingkat keuntungan tinggi justru memiliki beban pajak yang rendah. Hal ini dapat dipengaruhi pendapatan yang seharusnya tidak dimasukkan sebagai objek pajak tetapi dimasukkan sebagai objek pajak.

Pada penelitian ini penulis memilih menggunakan perusahaan manfaktur yang terdaftar di Bursa Efek Indonesia, dikarenakan perusahaan manufaktur merupakan perusahaan berskala besar sehingga dapat dilakukan perbandingan perusahaan satu dan lainnya. Hal lainnya adalah karena sebagian besar produk manufaktur tetap dibutuhkan, sektor manufaktur lebih tahan krisis ekonomi sehingga sangat besar kemungkinan untuk membukukan laba, dengan alasan ini penulis ingin mengetahui mengenai agresivitas pajak yang dilakukan pada sektor perusahaan manufaktur. Beberapa penelitian di atas terdapat inkonsistensi hasil penelitian mengenai pengaruh earnings management, size dan profitabilitas terhadap agresivitas pajak, penulis tertarik untuk menguji kembali pengaruh earnings management, size dan profitabilitas terhadap agresifitas pajak pada perusahaan manufaktur sektor otomotif tahun 2015-2019 yang terdaftar di BEI.

\section{LANDASAN TEORI DAN PENGEMBANGAN HIPOTESA Agresivitas Pajak}

Definisi agresivitas pajak adalah kegiatan perencanaan pajak semua perusahaan yang terlibat dalam usaha mengurangi tingkat pajak yang efektif (Hlaing, 2012). Selain itu, menurut (Hanlon, et al., 2010) agresivitas pajak adalah tingkatan akhir dari spectrum serangkaian perilaku perencanaan pajak. Agresivitas pajak ini hampir terjadi di semua perusahaan besar maupun kecil di seluruh dunia. Tindakan agresivitas pajak dilakukan dengan tujuan utama meminimalkan besarnya biaya pajak atau usaha untuk mengurangi pajak. Menurut Frank et al (2009), tindakan agresivitas pajak terbagi menjadi 2 cara, yaitu:

1. Penghindaran pajak (Tax Avoidance): suatu usaha wajib pajak dalam meminimalisir beban pajak. Cara ini menggunakan alternatif nyata (riil) yang dapat diterima oleh fiskus/pejabat pajak dan masih dalam lingkup peraturan perundang-undangan.

2. Penggelapan pajak (Tax Evasion): strategi penghindaran pajak yang dilakukan secara illegal dengan cara menyembunyikan keadaan yang sebenarnya, yakni dengan metode yang tidak terdapat dalam lingkup peraturan perpajakan.

Tindakan agresivitas pajak dapat diukur dengan berbagai cara, salah satunya menggunakan effective tax ratio (ETR). (Lanis, et al., 2012) menggunakan ETR dalam penelitiannya dengan alasan beberapa penelitian sebelumnya telah menggunakan rasio ini dalam pengukuran agresivitas pajak. Semakin rendah nilai ETR mengindikasikan adanya agresivitas pajak dalam perusahaan. ETR yang rendah menunjukkan beban pajak penghasilan yang lebih kecil dari pendapatan sebelum pajak.

\section{Manajemen Laba}

(Wirakusuma, 2011) berpendapat bahwa manajemen laba adalah suatu proses yang disengaja dengan batasan akuntansi keuangan untuk mengarahkan pelaporan laba pada tingkat tertentu. Manajemen laba adalah salah satu faktor yang dapat mengurangi kredibilitas laporan keuangan dan menambah bias serta menganggu pemakai laporan keuangan yang percaya pada angka hasil rekayasa tersebut sebagai angka real. Manajemen laba dilakukan dengan mempermainkan komponen akrual dalam laporan keuangan atau memanipulasi. Perilaku 
manajemen laba bukan hal yang merugikan selama dilakukan dalam koridor akuntansi, karena terdapat beberapa metode yang dapat digunakan dan bukan sebagai suatu larangan (Kusumawardhani, 2012). Perilaku manajemen laba merupakan salah satu bentuk tindakan creative accounting dari manajer yang tidak muncul dengan sendirinya, melainkan terdapat motivasi tertentu dibalik perilaku tersebut (Sulistiawan, 2011). Motivasi manajer melakukan manajemen laba adalah:

1. Bonus Plan Hypothesis, menyatakan bahwa rencana bonus atau kompensasi manajerial akan cenderung memilih dan menggunakan metode-metode akuntansi yang membuat laba dilaporan lebih tinggi.

2. Debt (Equity) Hypothesis, menyatakan bahwa perusahaan yang mempunyai rasio antara utang dan ekuitas lebih besar, cenderung memilih dan menggunakan metode akuntansi dengan laporan laba yang lebih tinggi serta cenderung melanggar perjanjian utang apabila ada manfaat yang diperoleh.

3. Political Cost Hypotesis, menyatakan semakin besar perusahaan, semakin besar pula kemungkinan perusahaan tersebut memilih metode akuntansi yang menurunkan laba. Hal tersebut dikarenakan laba yang tinggi membuat pemerintah akan segera melakukan tindakan seperti mengenakan peraturan kenaikan pajak pendapatan.

Penelitian terdahulu mengenai manajemen laba berkaitan dengan agresivitas pajak dilakukan oleh (Neifar, 2016) yang menguji motivasi terjadinya manajemen laba dan tingkat agresivitas keuangan pada perusahaan yang terdaftar di NASDAQ 100 setelah terjadinya krisis keuangan, menghasilkan kesimpulan yang menyoroti perilaku CEO dan karakteristik CEO, struktur tatakelola dan pengurangan biaya audit. Perusahaan merancang secara baik upaya untuk memperkecil beban pajak yang ditanggungnya, dan manajer dituntut untuk mengusai situasi yang dihadapi serta diharapkan dapat melakukan perencanaan pajak secara tepat dan menyeluruh terhadap transaksi yang berpengaruh terhadap perpajakan.

\section{Profitabilitas}

Profitabilitas adalah kemampuan perusahaan untuk memperoleh keuntungan. Menurut (Sudarmadji, et al., 2007) profitabilitas merupakan indikator kinerja yang dilakukan manajemen dalam mengelola kekayaan perusahaan yang ditunjukkan dengan laba yang dihasilkan. Laba dijadikan indikator oleh stakeholder untuk menilai sejauh mana kinerja manajemen mengelola perusahaan. Perusahaan yang mempunyai tingkat profitabilitas tinggi dapat menarik investor untuk menanamkan modal karena manajemen perusahaan dianggap berhasil menjalankan operasional perusahaan. Sebaliknya jika perusahaan memiliki tingkat profitabilitas rendah maka investor cenderung tidak tertarik menanamkan modalnya (Sudana, et al., 2011).

Tujuan utama yang ingin dicapai perusahaan adalah memperoleh laba atau keuntungan yang maksimal. Untuk mengukur tingkat keuntungan, aka digunakan rasio profitabilitas. Menurut (Brigham , et al., 2010) rasio profitabilitas adalah sekelompok rasio yang menunjukkan gabungan efek-efek dari likuiditas, makanejemn aktiva dan utang pada hasil operasi. Rasio profitabilitas ini biasanya dijadikan bahan pertimbangan investor dalam menanam sahamnya, bila suatu perusahaan memiliki tingkat profitabilitas tinggi terhadap pengembalian saham, maka investor akan memilih perusahaan tersebut dalam investasinya.

Penelitian ini menggunakan proksi ROA untuk mengukur profitabilitas karena ROA dapat menunjukkan kemampuan perusahaan memperoleh keuntungan dari penggunaan aset perusahaan. Semakin tinggi rasio ROA, maka semakin tinggi profitabilitas dalam perusahaan. Kenaikan ROA mengakibatkan kenaikan ETR sehingga ROA berpengaruh positif terhadap ETR. Akan tetapi 
seiring perkembangan jaman dan perubahan kebijakan perpajakan, hubungan ROA dan ETR menjadi negatif (Gupta, et al., 1997).

\section{Size (Ukuran Perusahaan)}

Ukuran perusahaan menunjukkan identitas perusahaan baik skala kecil maupun skala besar. Menurut (Bringham, et al., 2010) ukuran perusahaan adalah ukuran besar kecilnya sebuah perusahaan yang ditunjukan atau dinilai oleh total aset, total penjualan, jumlah laba, beban pajak dan lain-lain. (Hartono, 2013) menambahkan bahwa ukuran perusahaan merupakan besar kecilnya perusahaan yang dapat diukur dari total aktiva/besar harta perusahaan dengan menggunakan perhitungan nilai log total aktiva. Oleh karena itu, kualitas laporan keuangan harus transparan, terpercaya, dan terbebas dari manajemen laba karena dapat mengaburkan informasi yang tersedia. Terutama untuk informasi yang berkaitan dengan minimalisasi laba untuk meminimalkan pendapatan kena pajak sehingga pembayaran pajak menjadi minim.

Tabel 1. Kriteria Ukuran Perusahaan

\begin{tabular}{|l|l|l|}
\hline \multirow{2}{*}{ Ukuran Perusahaan } & \multicolumn{2}{|c|}{ Kriteria } \\
\cline { 2 - 3 } & \multicolumn{1}{|c|}{ Aset } & \multicolumn{1}{c|}{ Penjualan Tahunan } \\
\hline Usaha Mikro & Maks 50 juta & Maks 300 Juta \\
\hline Usaha Kecil & $>50$ Juta -500 Juta & $>300$ Juta $-2,5 \mathrm{M}$ \\
\hline Usaha Menengah & $>500$ Juta $-10 \mathrm{M}$ & $2,5 \mathrm{M}-50 \mathrm{M}$ \\
\hline Usaha Besar & $>10 \mathrm{M}$ & $>50 \mathrm{M}$ \\
\hline
\end{tabular}

Sumber: UU no 20 Tahun 2008

\section{HIPOTESIS}

\section{Pengaruh earnings manajemen terhadap agresivitas pajak}

Manajemen laba merupakan tindakan manajer untuk melaporkan laba yang dapat memaksimalkan kepentingan pribadi atau perusahaan dengan menggunakan kebijakan akuntansi. Laba yang berkualitas merupakan pencerminan kelanjutan laba saat ini untuk di masa depan. Manajer dalam kondisi ini berusaha untuk membuat laba perusahaan menjadi rendah, tujuannya agar beban pajak juga menjadi rendah. Berdasarkan uraian tersebut, maka hipotesis yang diajukan pada penelitian ini adalah sebagai berikut:

H1: earnings manajemen berpengeruh terhadap agresivitas pajak.

\section{Pengaruh profitabilitas terhadap agresivitas pajak}

Profitabilitas merupakan kemampuan pengelolaan perusahaan untuk memperoleh keuntungan dari operasional yang dilakukan. Profitabilitas diukur berdasarkan ROA yang mencerminkan kemampuan manajemen perusahaan dalam pencapaian laba perusahaan. Perusahaan yang memiliki keuntungan harus mempersiapkan pajak yang dibayarkan sebesar pendapatan yang diperoleh. Perusahaan dengan profitabilitas yang tinggi akan membayar pajak dengan nominal tinggi, begitu pula sebaliknya (Lestari, et al., 2016). Berdasarkan uraian tersebut, maka hipotesis yang diajukan pada penelitian ini adalah sebagai berikut:

$\mathrm{H} 2$ : Profitabilitas berpengaruh terhadap agresivitas pajak

\section{Pengaruh size terhadap agresivitas pajak}

Penelitian yang dilakukan oleh (Riyanto, 2008) menyimpulkan bahwa ukuran perusahaan yang dinilai dari besarnya equity, nilai penjualan, dan nilai aktiva sehingga suatu perusahaan dapat dikategorikan. Perusahaan skala besar memiliki perencanaan pajak yang matang dan mengadopsi praktek akuntansi yang efektif untuk menurunkan ETR perusahaan. Begitu pula dengan aset yang 
dimiliki perusahaan berhubungan serta dengan ukuran suatu perusahaan, semakin besar perusahaan, maka semakin besar aset perusahaan. Berdasarkan uraian tersebut, maka hipotesis yang diajukan pada penelitian ini adalah sebagai berikut:

H3: Ukuran perusahaan (size) berpengaruh terhadap agresivitas pajak.

Dalam penelitian ini penulis menggunakan variabel bebas dan varibel terikat sebagai berikut:.

\section{METODE PENELITIAN \\ Desain penelitian}

Desain penelitian merupakan kerangka atau perincian prosedur kerja yang akan dilkukan saat meneliti, sehingga diharapkan dapat memberikan gambaran dan arah saat melakukan penelitian (Fachruddin, 2009). Untuk mempermudah melakukan penelitian, maka dibawah ini adalah desain penelitian yang disajikan dalam bentuk bagan yang berkaitan dengan permasalahan penelitian.

Variabel Independen

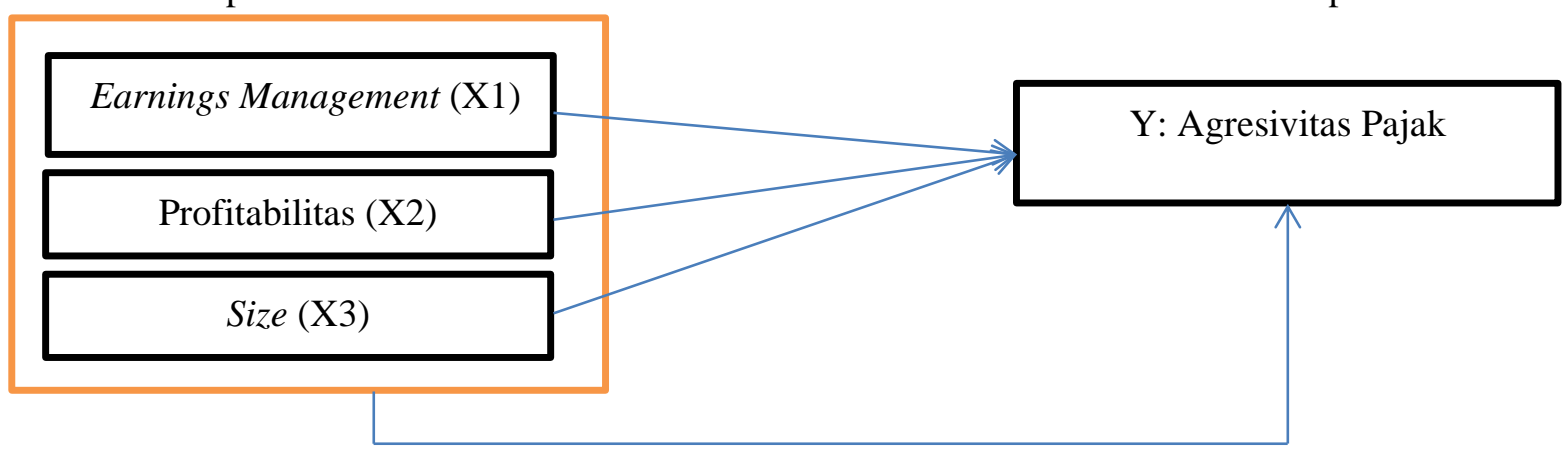

Gambar 1. Desain Penelitian

Sumber: hasil olahan Penulis (2020)

Variabel independen pada penelitian ini adalah agresivitas pajak sedangkan variabel dependen dalam penelitian ini yaitu X1 adalah Earnings Management, X2 adalah profitabilitas dan X3 adalah Size.

Penelitian ini tergolong penelitian kausal yakni penelitian yang dilakukan untuk menemukan penyebab dari satu atau lebih masalah. Dimana peneliti ingin menganalisis pengaruh variabel independen terhadap variabel dependen. Dalam penelitian ini akan menjelaskan pengaruh earnings management, profitabilitas dan size sebagai variabel independen terhadap agresifitas pajak sebagai variabel dependen.

Penelitian ini menggunakan populasi perusahaan manufaktur sub sektor otomotif yang terdaftar di BEI tahun 2015-2019. Alasan penggunaan perusahaan manufaktur pada penelitian ini karena perusahaan manufaktur merupakan perusahaan berskala besarsehingga dapat dilakukan perbandingan perusahaan satu dan lainnya. Hal lainnya adalah karena sebagian besar produk manufaktur tetap dibutuhkan, sektor manufaktur lebih tahan krisis ekonomi sehingga sangat besar kemungkinan untuk membukukan laba, dengan alasan ini penulis ingin mengetahui mengenai agresivitas pajak yang dilakukan pada sektor perusahaan manufaktur khusunya sub sektor otomotif karena dari tahun ke tahun mengalami perkembangan yang baik. Penulis menggunakan teknik purposive random sampling, maka didapatkan sample sebanyak 55 perusahaan. 
Tabel 2. Hasil seleksi sampel

\begin{tabular}{|l|l|l|}
\hline 1 & Manufaktur sub sektor Otomotif yang terdaftar di BEI 2015-2019 & 13 \\
2 & Perusahaan yang delisting periode 2015-2019 & $(0)$ \\
3 & Perusahaan yang datanya tidak lengkap & $(2)$ \\
4 & Jumlah Sampel & 11 \\
\hline
\end{tabular}

Penulis menggunakan teknik pengumpulan data berupa studi pustaka dan dokumentasi dengan mengumpulkan data yang telah tersedia. Data yang digunakan adalah data sekunder dengan menggunakan informasi pada laporan keuangan dari situs resmi, web resmi perusahaan dan literatur lain yang berkaitan.

Penelitian ini menggunakan metode analisis regresi berganda. Metode analisi penelitian ini mencakup uji deskriptif, analisis statisik, uji hipotesis, uji koefisien determinasi, uji parsial dan analisis regresi linier berganda. Berikut estimasi persamaan regresi penelitian ini:

$\mathrm{Y}=\alpha 0+\alpha 1 \mathrm{X} 1+\alpha 2 \mathrm{X} 2+\alpha 3 \mathrm{X} 3+\varepsilon$

Tabel 3. Keterangan Variabel

\begin{tabular}{|l|l|}
\hline Variabel & Keterangan \\
\hline $\mathrm{Y}$ & Agresivitas Pajak \\
\hline $\mathrm{X} 1$ & Earnings Management \\
\hline $\mathrm{X} 2$ & Profitabilitas \\
\hline $\mathrm{X} 3$ & Size \\
\hline
\end{tabular}

Desain penelitian yang digunakan adalah metode kuantitatif deskriptif, yaitu berdasarkan data yang dikumpulkan selama penelitian dengan sistematis berupa fakta dan sifat dari objek yang diteliti, kemudian diinterpretasikan berdasarkan teori dan literatur yang berhubungan. Instrument yang digunakan dalam penelitian ini merupakan instrument yang sesuai dengan rumus setiap variabel.

\section{Variabel Dependen}

Agresivitas pajak merupakan upaya perusahaan untuk meminimalisir beban pajak melalui tax planning activities dengan tujuan memaksimalkan nilai perusahaan. Agresivitas pajak pada penelitian ini diukur dengan Effective Tax Rate (ETR) yaitu perbandingan antara pajak riil yang dibayar perusahaan dengan laba komersial sebelum pajak. Tarif pajak efektif atau ETR dipakai untuk mengukur pajak yang dibayarkan sebagai proporsi dari pendapatan ekonomi (Ardianyah, et al., 2014). Berikut adalah rumus untuk mencari Effective Tax Rate:

$\mathrm{ETR}=\underline{\text { Beban Pajak penghasilan }} \times 100 \%$

Laba sebelum pajak

\section{Variabel Independen}

\section{Earnings Management}

Earnings Management (Manajemen Laba) adalah cara menyajikan laba yang disesuaikan dengan tujuan manajer yang dilakukan melalui pengelolaan akrual (Novianti, 2009). (Copeland, 1968) mendefinisikan manajemen laba adalah "some abilty to increase or decrease reported net income at will" dimana artinya manajemen laba mencakup usaha menajemen untuk memaksimumkan atau meminimumkan laba termasuk perataan laba sesuai yang diinginkan perusahaan. 
Rumus untuk menghitung manajemn laba adalah sebagi berikut: Manajemen Laba $=\underline{\text { Akrual Modal Kerja }}$

Penjualan

Akrual modal kerja $=$ arus kas dari aktivitas operasi

Rumus untuk akrual modal kerja $=\Delta$ Aset Lancar $-\Delta$ Hutang Lancar $-\Delta$ kas

$\Delta$ Aset Lancar $\quad=$ perubahan aset lancar pada akhir periode $\mathrm{t}$

$\Delta$ Hutang Lancar $=$ perubahan hutang lancar pada akhir periode $\mathrm{t}$

$\Delta$ kas $\quad=$ perubahan kas dan setara kas pada akhir periode $\mathrm{t}$

Proksi yang digunakan dalam penelitian ini adalah model spesifikasi akrual yaitu modal kerja yang juga digunakan dalam penelitian (Wiwik, 2005). (Peasnell, 2000) menyatakan bahwa penggunaan rasio modal kerja dengan penjualan lebih tepat, alasan penggunaan penjualan sebagai deflator akrual modal kerja adalah karena manajemen laba banyak terjadi di akun penjualan.

2. Profitabilitas

Profitiabilitas adalah kemampuan pengelolaan perusahaan untuk memperoleh laba maksimal. Pada penelitian ini menggunakan proksi Return of Aset (ROA) untuk mengukur tingkat profitabilitas perusahaan, karena ROA menunjukkan efektifitas perusahaan dalam mengelola aktiva. Pengelolaan aktiva dari modal sendiri maupun pinjaman, investor dapat melihat seberapa efektif perusahaan dalam mengelola aset (Rinaldi, 2015). Semakin tinggi rasio ROA, maka semakin tinggi profitabilitas dalam perusahaan. Kenaikan ROA mengakibatkan kenaikan ETR sehingga ROA berpengaruh positif terhadap ETR. Akan tetapi seiring perubahan dan perkembangan kebijakan perpajakan, hubungan ROA dan ETR menjadi negative (Gupta, et al., 1997). Berikut rumus untuk mencari Return of Aset:

ROA $=\underline{\text { Laba bersih setelah pajak }} \times 100 \%$

Total aset

3. Size

Size adalah suatu ukuran yang dikelompokkan berdasarkan besar kecilnya perusahaan. Ukuran perusahaan pada penelitian ini diproksi dengan Ln total aset. Pemakaian natural Log (Ln) dimaksudkan untuk mengurangi fluktuasi data yang berlebihan tanpa mengubah proporsi dari nilai asal yang sebenarnya (Nurfadilah, 2016). Berikut rumus untuk mencari size:

Size $=\log ($ Total aset $)$

\section{HASIL DAN PEMBAHASAN}

1. Uji Deskriptif

Hasil uji deskriptif dari variabel yang digunakan dalam penelitian tersaji dalam tabel dibawah: 
Tabel 4. Pengujian statistik deskriptif

\begin{tabular}{|l|c|r|r|r|r|r|}
\hline & \multirow{2}{*}{ N Statistic } & Min Statistic & Max Statistic & \multirow{2}{*}{ Sum Statistic } & \multicolumn{2}{|c|}{ Mean } \\
\cline { 5 - 7 } & & & & & Statistic & Std Error \\
\hline MnjmnLaba & 55 & -1.047 & .171 & -1.976 & -359 & .0232 \\
\hline ROA & 55 & -.106 & .939 & 2.833 & .051 & .018 \\
\hline Agresivitas & 55 & 5.706 & 8.546 & 390.119 & 709.307 & .124 \\
\hline Size & 55 & -.129 & 2.363 & 20.313 & .369 & .063 \\
\hline $\begin{array}{l}\text { Valid N } \\
\text { (Listwise) }\end{array}$ & 55 & & & & & \\
\hline
\end{tabular}

Sumber: Hasil Olah Data

Berdasarkan tabel di atas, diketahui bahwa variabel manajemen laba (X1) memiliki nilai minimum sebesar -1,047 dan maksimum sebesar 0,171. Untuk variabel profitabilitas yang diukur dari ROA (X2), memiliki nilai minimum -0.106 dan maksimum 0.939 dengan nilai ratarata sebesar 0,051. Nilai minimal untuk variabel size (X3) yakni sebesar 5,706 dengan nilai maksimal sebesar 8,546 dengan rata-rata sebesar 7.093. sementara untuk variabel agresifitas (Y) memiliki nilai minimal sebesar -0,129 dengan nila maksimal 2,363 dan rata-rata sebesar 0,369.

2. Uji Normalitas

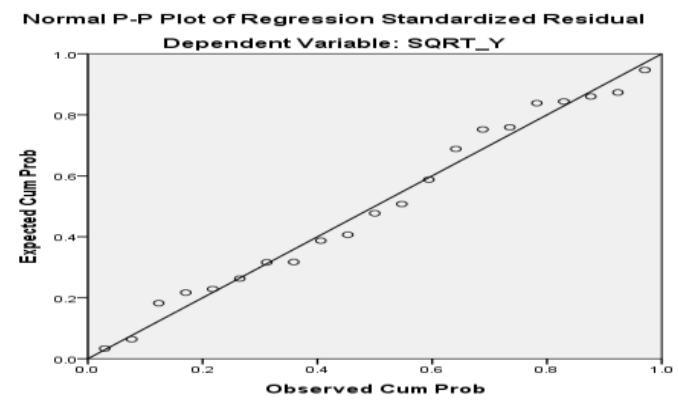

Gambar 2. Uji Normalitas

Dari gambar 1 di atas, dapat disimpulkan bahwa uji normalitas menggunakan P-Plot terlihat bahwa data terdistribusi normal. Hal ini didukung oleh titik ploting mengikuti dan mendekati garis diagonalnya.

3. Uji Multikolineraitas

Tabel 5. Hasil Uji Multikolineraitas

\begin{tabular}{|l|r|r|}
\hline \multirow{2}{*}{\multicolumn{1}{|c|}{ Model }} & \multicolumn{2}{|c|}{ Collinerity Statistics } \\
\cline { 2 - 3 } Tollerance & \multicolumn{1}{l|}{ VIF } \\
\hline (Constant) & & \\
\hline MnjmnLaba & .910 & 1.099 \\
\hline ROA & .958 & 1.044 \\
\hline Size & .921 & 1.086 \\
\hline
\end{tabular}

Sumber: Hasil Olah Data 
Hasil uji multikolineritas menunjukkan bahwa hasil pengujian di atas diketahui nilai VIF Manajemen Laba (1,099), VIF Variabel probabilitas (1,044) dan VIF variabel Size $(1,086)$, karena semua nilai VIF dibawah nilai 10 dan nilai tolerance di atas $10 \%$, sehingga dapat disimpulkan tidak terjadi masalah multikolineritas.

4. Uji Heterokedastisitas

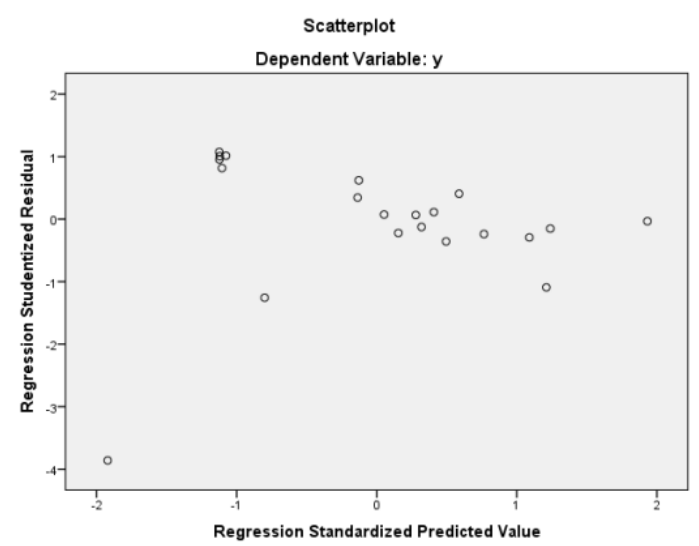

Gambar 3. Hasil Uji Heterokedastisitas

Hasil uji heterokedastisitas menunjukkan bahwa titik-titik pada scatterplot menyebar dan tidak terbentuk pola sehingga dapat disimpulkan bahwa model regresi tidak terdapat masalah heterokedastisitas.

5. Uji Autokorelasi

Tabel 6. Hasil Uji Autokorelasi

\begin{tabular}{|c|c|c|c|c|c|}
\hline Model & \multicolumn{4}{|c|}{ Change Statistic } & \multirow{2}{*}{ Durbin-Watson } \\
\hline & F Change & df1 & df2 & Sig. F Change & 1.724 \\
\hline 1 & .927 & 3 & 51 & .435 & \multirow{2}{*}{. } \\
\hline
\end{tabular}

Model regresi pada penelitian ini telah lolos uji asumsi klasik. Hasil uji autokorelasi menunjukkan bahwa nilai Durbin Watson (DW) hitung sebesar 1,724. Nilai dU dalam tabel dengan jumlah sampel 55 dan variabel sebanyak 4 adalah sebesar 1,68149 dan nilai dl 1,45232. Nilai d hitung terletak antara dU $(1,681)$ dan 4-dU $(2,54768)$, sehingga disimpulkan tidak terdapat masalah autokorelasi.

6. Uji Signifikansi Parsial (uji T)

Tabel 5. Hasil Uji Signifikansi Parsial

\begin{tabular}{|l|l|l|l|l|}
\hline \multirow{2}{*}{ Model } & \multicolumn{2}{|c|}{ Unstandardized Coefficients } & \multirow{2}{*}{$\mathrm{t}$} & Sig. \\
\cline { 2 - 3 } & $\mathrm{B}$ & Std. Error & \multicolumn{1}{|c|}{$\mathrm{t}$} \\
\hline (Constant) & -.017 & .279 & -.062 & .951 \\
\hline MnjmnLaba & .225 & .234 & .959 & .351 \\
\hline ROA & -.393 & .104 & -3.767 & .002 \\
\hline Size & .219 & .100 & 2.189 & .043 \\
\hline
\end{tabular}

Sumber: Hasil Olah Data 
Berdasarkan hasil uji signifikansi parsial, didapatkan kesimpulan sebagai berikut:

a. Variabel X1 yaitu earnings management diperoleh nilai signifikansi sebesar 0,351. Nilai ini lebih besar dari alpha yakni 0,05, sehingga dapat disimpulkan bahwa variabel earnings management tidak berpengaruh terhadap agresivitas pajak.

b. Variabel X2 yaitu profitabilitas diperoleh nilai signifikansi sebesar 0,002, dimana nilai ini lebih kecil dari Alpha (0,05), sehingga dapat disimpulkan bahwa variabel profitabilitas berpengaruh terhadap agresivitas pajak.

c. Variabel X3 yaitu ukuran perusahaan diperoleh nilai signifinaksi sebesar 0,043<0,05 sehingga dapat disimpulkan bahwa variabel size berpengaruh terhadap agresivitas pajak.

7. Uji Signifikansi Simultan (Uji F)

Tabel 6. Hasil Uji Signifikansi Simultan

ANOVA $^{\mathrm{a}}$

\begin{tabular}{lll|l|l|l|l} 
Model & & Sum of Squares & Df & Mean Square & F & Sig. \\
\hline 1 & Regression & .152 & 3 & .051 & 9.664 & $.001^{\mathrm{b}}$ \\
\cline { 2 - 7 } & Residual & .089 & 17 & .005 & & \\
\cline { 2 - 7 } & Total & .242 & 20 & & & \\
\hline
\end{tabular}

a. Dependent Variable: SQRT_Y

a. Predictors: (Constant), SQRT_X3,SQRT_X2,SQRT_X1

Uji Signifikansi simultan ini dilakukan untuk mengetahui apakah variabel dependen secara bersama-sama dipengaruhi variabel independen. Berdasarkan uji signifikansi di atas, diperoleh nilai sebesar 0,001, dimana nilai ini lebih kecil dari 0,05 (Alpha) sehingga dapat disimpulkan bahwa model regresi linier diestimasi layak untuk menjelaskan pengaruh eranings management, profitabilitas dan size terhadap agresifitas pajak, dan dapat dikatakan bahwa semua variabel independen secara bersama-sama mempengaruhi variabel independen.

8. Analisis Koefisien Determinasi $\left(\mathrm{R}^{2}\right)$

Tabel 7. Hasil analisis koefisien determinasi

\begin{tabular}{|c|c|c|c|c|c|}
\hline \multicolumn{6}{|c|}{ Model Summary } \\
\hline Model & $\mathrm{R}$ & R Square & $\begin{array}{l}\text { Adjusted } \\
\text { Square } \\
\end{array}$ & $\mathrm{R}$ & $\begin{array}{l}\text { Std. Error of the } \\
\text { Estimate }\end{array}$ \\
\hline 1 & $.794^{\mathrm{a}}$ & .630 & .565 & & .07250 \\
\hline
\end{tabular}

a. Predictors: (Constant), SQRT_X3,SQRT_X2,SQRT_X1

b. Dependent Variable: SQRT_Y

Nilai koefisien determinasi pada penelitian ini adalah sebesar 0,565 menunujukkan bahwa kemampuan variabel independen dalam menerangkan variabel dependen sebesar 56,5\%. Dengan demikian, dapat disimpulkan bahwa variabel dependen penelitian ini yaitu agresifitas pajak dapat dijelaskan oleh variabel earnings management, profitabilitas dan size. Sedangkan sisanya (100\%$56,5 \%=43,5 \%$ ) dijelaskan faktor lain diluar penelitian. 


\section{Earnings Management tidak berpengaruh pada agresivitas pajak}

Berdasarkan hasil regresi penelitian ini, variabel earning management memiliki nilai signifikansi 0,351 lebih besar dari alpha $(0,05)$, sehingga dapat dikatakan bahwa variabel earning management tidak berpengaruh terhadap agresivitas pajak. Hal ini sejalan dengan penelitian yang telah dilakukan oleh (Cahyani, 2016) yang menyatakan bahwa manajemen laba tidak berpengaruh terhadap agresivitas pajak. Hal ini dapat dijelaskan karena ketentuan Undang-Undang Pajak Penghasilan dan PSAK yang berkaitan dengan pendapatan dan beban tidak sama, karena memiliki tujuan yang berbeda. Perbedaan antara pajak dan akuntasni dapat dibedakan menjadi dua, yakni tetap dan temporer (Kamila, et al., 2014). Pada perbedaan tetap disebabkan oleh perbedaan pengakuan pendapatan dan beban antara standar akuntansi dan peraturan perpajakan, sementara untuk temporer adalah karena adanya perbedaan waktu dan metode pengakuan penghasilan. Apabila terdapat kemungkinan pembayaran pajak yang lebih kecil pada tahun berikutnya, disebut aset pajak tangguhan, sedangkan jika terdapat kemungkinan pemyaran lebih besar, maka disebut kewajiban tanguhan (Suandy, 2014). Contoh lainnya yakni perbedaan masa manfaat aset tetap antara ketentuan pajak dan kebijakan perusahaan dalam menilai penyusutan. Akibatnya terdapat perbedaan antara nilai buku aset dalam laporan keuangan dengan dasar pengenaan pajaknya. Setiap akhir pelaporan , perusahaan melakukan rekonsiliasi fiskal atas laba sebelum pajak untuk menghitung Penghasilan Kena Pajak (PKP), sehingga meskipun perusahaan menggunakan manajemen laba, tidak akan berdampak terhadap tujuan meminimalkan pajak karena adanya perbedaan ketentuan berkaitan dengan pengakuan pendapatan dan beban.

\section{Profitabilitas berpengaruh pada agresivitas pajak}

Berdasarkan hasil regresi penelitian ini, nilai signifikansi variabel profitabilitas sebesar 0,002 lebih kecil dari Alpha $(0,005)$ dapat ditarik kesimpulan bahwa variabel ini berpengaruh terhadap agresivitas pajak. Hal ini sesuai dengan penelitian yang dilakukan oleh (Lestari, et al., 2016). Nilai Return on Asset (ROA) yang tinggi menunjukkan bahwa perusahaan telah memanfaatkan asetnya secara efektif dan efisien, sehingga perusahaan mampu membayara bebanbebannya termasuk beban pajak. Kesadaran dalam ttertib membayar pajak, akan berpengaruh dalam membuat citra positif untuk menarik investor, masyarakat umum, maupun otoritas perpajakan.

\section{Size (Ukutan Perusahaan) berpengaruh pada agresivitas pajak}

Berdasarkan hasil regresi penelitian ini, nilai hitung signifikansi variabel size adalah sebesar 0,043 lebih kecil dari Alpha (0,05), sehingga dapat ditarik kesimpulan bahwa variebl ukuran perusahaan ini berpengaruh terhadap agresivitas pajak. Hasil ini sesuai dengan penelitian yang telah dilakukan oleh (Tiaras, et al., 2015). Hal ini dapat dijelaskan karena ukuran perusahaan yang besar memperoleh keuntungan political power sehingga lebih agresif terhadap pajak dibandingkan dnegan perusahaan dengan ukuran yang lebih kecil (Hsieh, 2012). Perusahaan dengan ukuran besar dapat mempengaruhi regulasi perpajakan sehingga secara tidak alngsung memiliki dampak signifikan terhadap agresivitas pajak.

\section{KESIMPULAN DAN SARAN}

Berdasarkan penelitian yang dilakukan, dihasilkan kesimpulan bahwa manajemen laba tidak berpengaruh terhadap agresivitas pajak, naming untuk variabel profitabilitas dan ukuran perusahaan berpengaruh pada agresivitas pajak. Dalam penelitian ini masih banyak kekurangannya sehingga diharapkan bagi penelitian selanjutnya perlu dilakukan penambahan dalam pengambilan 
data seperti survey dan wawancara, penambahan variabel lain yang belum tercantum dalam penelitian ini, seperti susunan manajerial, rasio modal, rasio persediaan dan lain sebagainya.

Saran untuk penelitian selanjutnya adalah perlunya dilakukan penambahan variabel lainnya serta menggunakan sampel subsektor perusahaan lain supaya diketahui hasil secara lebih umum.

\section{DAFTAR PUSTAKA}

Andhari Ayu and Sukartha Pengaruh Corporate Social Responsibility, Profitabilitas, Inventory Intensity, Capital Intensity dan Leverage pada Agresivitas Pajak [Journal] // E-Journal Akuntansi Universitas Udayana. - 2017.

Ardianyah Danish and Zulaikha Pengaruh Size, leverage, Profitability, Capital Intensity Ratio dan Komisaris Independen terhadap Effectife Tax Ratio (ETR) [Book]. - Semarang : Universitas Diponegoro, 2014.

Bringham Eugene and Houston Joel Dasar-Dasar Manajemen Keuangan [Book]. - Jakarta : Salemba Empat, 2010.

Cahyani Risma Pengaruh Manajemen Laba dan Corporate Social Responsibilty terhadap Agresivitas Pajak [Book]. - Jakarta : UIN Syarif Hidayatullah, 2016.

Chen Are Family Firm More tax Aggressive Than non family Firm? [Journal] // Journal of Financial Economics. - 2010. - pp. 41-61.

Copeland R.M Income Smoothing [Journal] // Journal Of Accounting Research, Empirical Research in Accounting, Selected Studies 6. - 1968. - pp. 101-116.

Gupta S and Newberry K Determinants of The Variability on Corporate Effective Tax rates: Evidance From Longitudinal Data [Journal] // Journal of Accounting and Public Policy, 16 (1). - 1997. - pp. 1-34.

Haiwei Tjendraputra Pengarih Modernisasi Sistem Administrasi Perpajakan Terhadap Tingkat Kepatuhan Pengusaha Kena Pajak pada Lokasi Pusat Bisnis dan Perdagangan di Kawasan Tanjung Perak [Book]. - Surabaya : Universitas Widya Mandala, 2014.

Hanlon Michelle and Heitzman Shane A Review of tax Research [Journal] // Journal of Accounting and Economics Vol 50. No 40. - 2010. - pp. 127-178.

Hartono Teori Portofolio dan Analisis Investasi Edisi Kelima [Book]. - Yogyakarta : BPFE, 2013.

Hlaing K.P Organizational and Architecture of Multinationals and Tax Aggresiviness. [Book]. - Canada : University of Waterloo, 2012.

Hsieh Yao-Chih New evidence on determinants of corporate effective tax rate [Journal] // African Journal of Business management 6 (3) . - 2012. - pp. 1177-1180.

Kamila Putri Almainda and Martani Dwi Analisi Hubungan Agresivitas Pelaporan Keuangan dan Agresivitas Pajak [Journal] // Simposium Nasional Akuntansi 17. - 2014.

Kuriah Hanik and Asyik Nur Pengaruh karakterisitik perusahaan dan Cprporate Social Responsibilty terhadap Agresivitas Pajak [Journal] // Journal Ilmu dan Riset Akuntansi Vol.5 No. 3. - 2016.

Kurniasih T and Sari M.M Pengaruh ROA, Leverage, Corporate Governance, Ukuran perusahaan dan KOmpensasi Rugi Fiskal pada Tax Avoidance [Journal] // Buletin Studi Ekonomi Vol. 18 No. 1. - 2013.

Lanis R and Richardson G Corporate Social Responsibility and tax Agressiveness: An Empirical Analysis [Journal] // Journal Accounting Public Policy. - 2012. - pp. 86-108.

Lestari Putri Citra and Febrianty Maya Pengaruh Capital Intensity Ratio, Inventory Intensity Ratio, Ownership Structure dan Profitability terhadap Effectife Tax Rate [Journal] // E-Journal Universitas Syiah Kuala Vol. 1 No.1 . 2016. - pp. 101-119.

Novianti L Penerapan Good Corporate Governance di Indonesia [Journal] // Jurnal Akuntasni dan Keuangan 14(2). - 2009. - pp. 211-232.

Nugraha Bani Meiranto and Meiranto Wahyu Pengaruh CSR, Ukuran Perusahaan, Profitabilitas, Leverage, Capital Intensity, terhadap Agresivitas Pajak (Studi empiris pada Perusahaan non Keuanganyang terdaftar di BEI 2012-2013) [Journal] // Diponegoro Journal Accounting Vol. 4 No. 4. - 2015. 
Nugraha Novia Bani Pengaruh Corporate Social Responsibilty, Ukuran Perusahaan, Profitabilitas, Leverage dan capital Intencity pada Agresivitas Pajak [Book]. - Semarang : Univierstas Diponegoro, 2015. Nurfadilah Pengaruh Leverage, Ukuran Perusahaan dan Kualitas Audit terhadap Penghindaran Pajak [Journal] // Syariah Paper Accounting Journal. - 2016.

Peasnell K. V Board Monitoring and Earnings Management: Do Outside Directors Influence Abnormal Accruals [Journal] // Journal Applied Financial Economics Vol. 12 No. 3. - 2000. - pp. 159-170.

Riyanto Bambang Dasar-Dasar Pembelanjaan Perusahaan [Book]. - Yogyakarta : GPFE, 2008.

Schipper Commentary on Eranings Management Accounting [Journal]. - [s.l.] : Horizon 3, 1989. - 91-102. Soemitro Perpajakan Edisi Revisi 2011 [Book]. - Yogyakarta : PT Andi, 2011.

Suandy Erly Hukum Pajak Edisi Kedua [Book]. - Jakarta : Salemba Empat, 2008.

Suandy Erly Perencanaan Pajak Edisi 5 [Book]. - Jakarta : Salemba Empat, 2014.

Sudana I Made and Arlindania Putu Ayu Corporate Governance dan pengungkapan Corporate Social Responsibility pada Perusahaan Go Public di Bursa Efek Indonesia [Journal] // Jurnal manajemen Teori dan Terapan Tahun. 4, No. 1. - 2011.

Sudarmadji Ardi Murdoko and Sularto Lana Pengaruh Ukuran Perusaaahn, Profitabilitas, Leverage dan Tipe Kepemilikan Perusahaan Terhadap Luas Voluntary Disclosure Laporan Keuangan Tahunan [Journal] // Proceeding PESAT, Vol. 2. - 2007.

Suyanto Krisnata Dwi and Supramono Pengaruh Likuiditas, Leverage, Komisaris Independen dan manajemen Laba terhadap Agresivitas Pajak Perusahaan [Journal] // journal Keuangan dan perbankan Vol. 16 No. 2. - 2012.

Tiaras Irvan and Henryanto Wijaya Pengaruh Likuiditas, Leverage, Manajemen Laba, KOmisarsi Independen dan Ukuran perusahaan terhadap Agresivitas Pajak [Journal] // Jurnal Akuntansi No. XIX, Vol. 3. - 2015.

Wiwik Utami Pengarih Manajemen Laba Terhadap Biaya ModalEkuitas (Studi pada Perusahaan Manufaktur) [Journal] // Simposium Nasional Akuntansi VIII 15-16. - 2005. - pp. 100-116. 